\title{
Impact of the Development of ICT Infrastructure and Security on the Effectiveness of Accounting Information in the Jordanian Banking Sector
}

\author{
Reem Oqab Hussein Al- Khasawneh ${ }^{1}$, Mohamed Mahmoud Mohamed bshayreh ${ }^{1}$, Mohamed Ali Al-Oqool ${ }^{1}$ \\ ${ }^{1}$ Al-Baqa Applied University -Al-Huson University college, Jordan \\ Correspondence: Reem Oqab Hussein Al- Khasawneh, Al-Baqa Applied University -Al -Huson University \\ college, Jordan.
}

Received: October 7, 2019

Accepted: November 13, 2019 Online Published: November 25, 2019

doi:10.5539/ibr.v12n12p93

URL: https://doi.org/10.5539/ibr.v12n12p93

\begin{abstract}
Information and communication technology ICT infrastructure is an essential foundation of the information society characterized by modernization and advance. ICT infrastructure consists of main five elements including physical resources, human resources, software, databases and networks and communication. The study aims at identifying the impact of the development of ICT infrastructure, which includes physical and human resources, software, databases and networks and communications, on the effectiveness of accounting information systems. To achieve the purposes of the study, a researcher has used a descriptive research methodology; a questionnaire has been distributed to the employees at various management and accounting positions in the bank.

The study found that the developments of ICT infrastructure, consisting of physical and human resources, software, databases and networks and communications, affects extremely the effectiveness and security of accounting information systems.
\end{abstract}

Keywords: information technology, effectiveness of information technology, information security

\section{Introduction}

Accounting information system is a significant part of business organizations and a main source of planning and monitoring processes. Availability of effectiveness property of accounting information system, therefore, is one of main factors of business organizations' success, particularly banks. ICT is a competitive feature in banking sector; it is used for providing banking services, transaction and banking processes. In addition, ICT provides management department with information on planning, monitoring and decision-making which mainly contributes to rationalize the decisions and succeed the administrative processes. Thus, providing such information meets management needs and contributes to achieve bank goals .

Effectiveness of accounting information systems is linked to a provision of ICT infrastructure which consists of physical and human resources, software, databases, and networks and communications providing and processing the data .

In light of the use of wire and wireless communication technology, banks shall provide programs of accounting data protection and confidentiality; bank and clients data shall be protected against the penetration which may distort bank reputation and cause financial losses. In addition, human resources specializing in these systems shall be provided; one of the most significant elements of infrastructure of banking accounting information systems is database. Techniques of the database and technological cloud systems have been developed in order to save the data and perform the processes .

Accordingly, Jordanian banking sector seeks to develop IT infrastructure and security and keep up with the changes and risks of accounting information systems; it also tries to ensure the effectiveness of accounting information systems and achieve competition feature .

\section{Purposes of the Study}

The study aims at identifying the following:

-The most important development of the elements of ICTinfrastructure and its role in achieving the effectiveness 
of accounting information system in Jordanian banks.

-To which extent Jordanian banks pay attention to develop ICT infrastructure and security and its impact on achieving the effectiveness of accounting information systems.

-The impact of the development of infrastructure elements, including physical and human resources, software, database, communications and networks, on achieving the effectiveness of accounting information system in banking sector.

-The role of the development of information security systems in Jordanian banking sector in achieving the effectiveness of accounting information systems.

\section{Importance of the Study}

This study is important because it identifies the development of IT infrastructure and its role in the effectiveness of accounting information systems in banking sector, the most significant part of economic sector .

This sector seeks to use highly IT in order to provide banking services and prepare the data. At present, banks depends greatly on ICT through using electronic sites in order to provide the services. However, using ICT is usually accompanied with various risks. Jordanian banks, therefore, seek to provide security and protection methods evolved according to the development of IT infrastructure and uses. As a result, the accompanied risks which may damage the accounting information and cause financial losses may be reduced. Consequently, a harmony between the development of IT infrastructure and its security shall be provided in order to achieve the effectiveness of accounting information systems .

\section{Problem of the Study}

Accelerated development of accounting information technology and its infrastructure is linked to information security in a way that achieves the effectiveness of accounting information systems. This study aims to answer the following questions :

-Does the development of ICT infrastructure, including physical and financial resources, software, databases, communication and networks, affect the effectiveness of e-banking information systems in Jordanian banks?

-Does the development of information system infrastructure and data security contribute to achieve the effectiveness of e-banking accounting systems in Jordanian banks?

\section{Hypotheses of the Study}

The study tests the following hypotheses -:

First hypothesis: There is no statistically significant relationship between the development of ICT infrastructure, including physical and financial resources, software, databases, communication and networks, and its security and the effectiveness of accounting information systems in Jordanian banks .

The study also tests the following sub-hypotheses related to the elements of ICT infrastructure :

There is no statistically significant relationship between the development of physical resources as a part of ICT infrastructure and the effectiveness of e-accounting information systems in Jordanian banks .

There is no statistically significant relationship between the development of software as a part of ICT infrastructure and the effectiveness of e-accounting information systems in Jordanian banks.

There is no statistically significant relationship between the development of databases as a part of ICT infrastructure and the effectiveness of e-accounting information systems in Jordanian banks.

There is no statistically significant relationship between the development of human resources as a part of ICT infrastructure and the effectiveness of e-accounting information systems in Jordanian banks.

There is no statistically significant relationship between the development of communications and networks as a part of ICT infrastructure and the effectiveness of e-accounting information systems in Jordanian banks.

Second hypothesis: There is no statistically significant relationship between the development of information security system as a part of ICT infrastructure and the effectiveness of e-accounting information systems in Jordanian banks.

\section{Previous Studies and Theoretical Framework}

Siyam study (2004), entitled 'Evaluation of the Effectiveness of Computerized Accounting Information Systems In Jordanian Commercial banks in the light of technological development', touched upon the evaluation of the effectiveness of accounting information systems; it examined a set of standards (i.e quality, flexibility, simplicity 
and reliability) which reflect the effectiveness of the performance of these systems. The researcher designed a questionnaire distributed to financial managers and employees working in financial departments of (9) nine Jordanian commercial banks listed in stock marks (Amman Stock Exchange) of the year of 2003. 45 questionnaires were distributed; 42 questionnaires were valid for the purposes of the analysis. The study found that computerized accounting information systems in Jordanian commercial banks have been characterized by the quality due to the accuracy and adequacy of the outputs of these systems in the light of technological development. In addition, the study showed that computerized accounting information systems in Jordanian commercial banks have been characterized by the flexibility, simplicity and reliability in the light of technological development; these features have been listed in a descending order as follows: quality, reliability, flexibility and simplicity. The study recommended that computerized accounting information systems should be developed .

Qatawneh study (2005), entitled 'Impact of the Use of Information Technology On the Effectiveness of accounting information systems: A case study of Banks and Insurance Companies listed in Amman Stock Exchange', aimed at identifying the impact of the use of information technology on the effectiveness of accounting information systems in banks and insurance companies listed in Amman Stock Exchange. The researcher designed two questionnaires in order to achieve the purposes of the study; the first aimed at measuring the effectiveness of accounting system; the second aimed at measuring the impact of information technology on the effectiveness of accounting information systems. Numbers of insurance and bank facilities were 10 and 13, respectively; 138 questionnaires had been distributed to 138 and 113 had been valid for analysing. The study found that the use of information system affected the effectiveness of accounting information systems; the most important factor has been the use of communication networks, followed by hardware and software, then databases. The study indicated that technology levels used by banking sector are higher than that used by insurance companies. The study recommended that information technology should be increasingly invested; technological developments should be kept with.

Fadel study (2007), entitled ' Extent of the Impact of Environmental, Regulatory, Behavioural, and Technological Factors on the Effectiveness of Accounting Information Systems in Commercial Banks in Republic of Yemen: A field Study', aimed at identifying the extent of the impact of environmental, regulatory, behavioural, and technological factors on the effectiveness of accounting information systems, whether these factors have been taken together or independently in financial departments and accounting sections. A study sample was composed of 340 employees working in Yemeni commercial banks. 172 questionnaires were analysed. The study found that when these factors were taken together, the technological and regulatory factors had affected the effectiveness of accounting information system. However, when these factors were taken independently, each one had a clear and positive impact on the effectiveness of accounting information systems used in Yemeni commercial banks. The study recommended that the employees and users should involve in the design and development of accounting information systems; computers and advanced software should be used; administrative decentralization system should be expanded .

Ghassan Falah Al-Matarneh and Jamal Adel Al-Shrairi study (2009), entitled 'Impact of Information Technology on The Effectiveness of Accounting Information Systems in Jordanian pharmaceutical companies', aimed at identifying the impact of information technology on the effectiveness of accounting information systems in Jordanian pharmaceutical companies; it also was to identify the impact of the use of hardware, software and databases on the effectiveness of accounting information systems in these companies. To achieve study purposes and to test study hypotheses, a questionnaire was designed and distributed to study sample composed of 42 respondents. Arithmetic mean, standard deviation and t-test were used for testing the hypotheses. The study found that using IT, hardware, software and databases affected the effectiveness of accounting information systems. The researcher recommended that the use of accounting and administrative information technology should be developed in accordance with work requirements and changes of external environment .

\section{Theoretical Framework of Study}

Due to new work environment, work organizations are forced to develop their traditional businesses and switch to e-business which is in line with modern tools and methods. At a present, businesses are directly provided on line via websites. In addition, financial statements are presented and submitted through e-disclosure via company website and Securities Commission website. Hence, IT infrastructure is important because it contributes greatly to achieve systems' goals and improve making-decision processes which depend on accurate and speedy information. Providing a sophisticated infrastructure with high capabilities of processing accounting data and information via new communication channels may increase the speed of information flow and exchange among administrative departments. The researchers unanimously agreed that the components of IT infrastructure are physical and human resources, software, databases and wireless networks ( Loudon \& laden 2003:176) and (Al-Abbadi 2006 pp. 36-45. (Effectiveness of accounting information systems is an ability of accounting system to achieve its goals 
such as a provision of appropriate and reliable information which helps decision-makers achieve their goals ( karfou, Mohsen, and Ahmad, 2016, P. 278 .(

Al-Matarneh and Al-Sharairi, 2010, P.102 pointed out that effectiveness of accounting information technology is the ability of the system to achieve its planned and desired goals .

The researcher has believed that if e-banking accounting system is effective, it will be able to achieve its assigned goals. Accordingly, the system is less or more effective according to its ability to achieve the assigned and desired goals. Regarding information security, accounting information system operates within a secure environment which makes the financial and accounting statements more reliable, confidential and integrated. In addition, accounting information is protected against the risks and threats which accompany IT .

Next section of the study outlines the role of IT infrastructure and security in the effectiveness of e-accounting information systems .

\section{Physical Resource as a Part of IT Infrastructure in the Banks and Its Role in Achieving the Effectiveness of E-accounting Information Systems}

Physical Resources are the equipment and hardware used for performing information systems' activities and tasks such as data entry, processing and output (Al-Shammari, 2013,P.12). The researcher believes that e-banking system infrastructure system is composed of banking data entry units, processing hardware and storage units. Then, the branch saves all the data in database until the end of accounting period including processes and operation files in order to be used at the end of fiscal year for preparing yearly financial report and interim data. Due to the development of banking information system, Banks have used large-sized computers for processing banking operations and terminal units for saving the data then transferring them to the management. However, small-sized computers, mobile devices and tablets have recently be used for data entry and processing by the banks because of the continuous development of computers. In addition, the banks have used a set of devices such as data readers which read cheques' data. Data entry and processing's development contributes to achieve the effectiveness of accounting information systems through the availability of the accuracy and reliability of data entry, thereby achieving the reliability of banking accounting data processing. With regard to the development of storage units and data transmission means, the development of material unit contributes to use databases, e-clouds which achieve confidentiality, reliability and integration of preparing e-banking accounting data and the speed of access to the data .

\section{Software as a Part of IT infrastructure in the Banks and Its Role in Achieving the Effectiveness of E-accounting Information Systems}

Software applied by e-banking accounting information system controls and manages physical resources through a set of detailed instructions and orders; it also controls all system operations and contributes to achieve accounting information system's goals; by using such system, specialized human resources can retrieve or modify the data, when necessary .

Software of e-banking accounting information system is composed of a set of programs required for operating the devices which regulate and control software's parts and accessories plus software applications specialized in banking works .

The development of software as a part of accounting information system infrastructure contributes to achieve the effectiveness of e-banking accounting system; working mechanism of material components of data processing and access are controlled; in addition, the data can be modified in order to achieve the reliability and integration .

Moreover, software of processing of banking operations has been developed; banking operations are processed and controlled by specialized advanced accounting banking applications. Banking software has evolved into electronic applications the clients can use for processing banking operations via electronic means such as smart phones and tablets; software of accounting information security attached to e-banking accounting applications has been developed in order to achieve the security of accounting information and ensure the confidentiality and reliability of banking accounting data; security and protection programs allow only authorized employees to access the data.

\section{Human resource as a Part of IT infrastructure in the Banks and Its Role in Achieving the Effectiveness of E-accounting Information Systems}

Human resource is one of significant components of IT infrastructure and contributes greatly to the success of accounting information system. Employees, therefore, shall be know the methods of using physical resources, software and operating this system. In addition, they shall know the methods of processing and preparing accounting data and reports. Continuous training for the employees contributes to achieve the effectiveness of 
accounting information system .

\section{Database as a Part of IT infrastructure in the Banks and Its Role in Achieving the Effectiveness of E-accounting Information Systems}

Database is one of essential components of IT infrastructure of e-banking accounting information system; it is a set of files and data linked mutually and organized within a logical framework; they are saved and can be retrieved in order to prepare necessary information. Database allows for data sharing among data users in work organizations including banks. The users are able to share the data when necessary; data sharing is managed in order to maintain data security through programs of database management; these programs can be used to protect the data against unauthorized access; they also ensure data reliability and the confidentiality and integration of preparing the data .

12. Networks and Communication Systems as Parts of IT infrastructure in the Banks and their Role in Achieving the Effectiveness of E-accounting Information Systems

Networks and communication systems are essential parts of modern e-banking accounting system; they contribute deeply to the success of banking activities and operations; in addition, they are key factors achieving competitive advantage and increasing bank profitability .

Networks and communication systems connect the operations and systems altogether; Networks and communication systems make data transferring and sharing inside the bank and between various banks and the central bank and correspondent banks easier; it is noted that various services provided by ATMs are acceptable; banking systems use a set of networks and communication systems which can be divided into :

\section{Specialized Internal Computer Networks}

They aim at providing a certain level of data protection and privacy while data is transferred and shared between bank branches, management and internal sections. These network applications are only used by authorized employees working in the banks; the banks can also use internal mail as e-application .

\section{Internet}

The bank uses internet in various fields; internet used by the bank includes a set of specialized protection programs with high levels of quality; the bank may use bank websites in order to provide e-banking services. Moreover, internet can be used to exchange the information and e-mails between correspondent banks, general administration and the central bank .

\section{Extranet}

It is an internal communication network which allows authorized persons to access a local network and perform certain tasks. Communication systems such as wire communications, wire transmission lines, data sharing and accessing, wireless communications, have highly developed. Because of continuous development of communication systems, various data protection programs have been invented and developed. Such programs protect the data against unauthorized access and modification, abuse of the banks and clients. Accordingly, these systems contribute to achieve the effectiveness of e-accounting system .

\section{Field Study}

\section{Study Methodology}

Analytical descriptive method has been used for describing accurately a phenomenon as it is in the reality. In addition, it has expressed the phenomenon quantitatively and qualitatively. It has based on two sources to collect the data :

\section{Primary sources}

A questionnaire has been designed and distributed to the employees working in various positions in Jordanian banks including bank branch manager, assistant branch manager, head of department, internal auditor.

\section{Secondary sources}

They include the literatures such as books, periodicals, researchers, reports, Arab and foreign publications related to the subject of the study. They also consist of governmental documents, laws and relevant systems .

\section{Study Tool}

The questionnaire has been designed to collect the data required for achieving study goals. likert five point scale has been employed in order to measure respondents' agreement with all questionnaire statements. The data has been converted into numerical results which can be statistically measured and described. Likert scale has five points as follows: agree strongly, agree, undecided, disagree, and disagree strongly. Numerical values range from 
$1-5$, respectively; these values give the weight of the responses .

\section{Study Population and Sample}

Study population consists of 15 banks listed in Amman Stock Exchange; 4 questionnaires have been distributed to each bank; 60 questionnaires have been distributed; 50 valid questionnaires have been retrieved .

\section{Validity and Reliability of Study Tool \\ Validity of Study Tool}

The questionnaire has been arbitrated by a group of academic professors specializing in accounting, auditing and statistics for ensuring the validity; their notes have been taken into consideration and some statements have been reformulated in order to achieve consistency and balance among questionnaire statements .

\section{Reliability of Study Tool}

Cronbach's alpha coefficient has been used for testing the validity of questionnaire results and an availability of internal consistency among questionnaire statements; an acceptable value of Alpha coefficient is $60 \%$ or more. Alpha coefficient has been applied to all parts of questionnaire; Table 1 illustrates that the value of Cronbach's alpha coefficient of respondents' answers to all questions and fields is higher than the acceptable value. It means that a high degree of internal consistency is available. As a result, study tool has a high level of reliability and its answers can be adopted for achieving study goals and analyzing the results. Table below outlines the results of Cronbach's alpha test :

Table 1. Consistency Coefficients extracted by Cronbach's Alpha

\begin{tabular}{|l|l|l|l|}
\hline \multicolumn{2}{|c|}{ Field } & \multicolumn{1}{c|}{ Results } \\
\cline { 2 - 4 } & $\begin{array}{l}\text { Number of } \\
\text { Question }\end{array}$ & Alpha Coefficient & Result \\
\hline $\begin{array}{l}\text { Development of physical resource as a part of ICT } \\
\text { infrastructure in the banks and its role in achieving the } \\
\text { effectiveness of e-accounting information systems }\end{array}$ & 5 & 87 & Accepted \\
\hline $\begin{array}{l}\text { Development of software as a part of ICT infrastructure in the } \\
\text { banks and its role in achieving the effectiveness of } \\
\text { e-accounting information systems }\end{array}$ & 15 & 72 & Accepted \\
\hline $\begin{array}{l}\text { Development of database as a part of ICT infrastructure in the } \\
\text { banks and its role in achieving the effectiveness of } \\
\text { e-accounting information systems }\end{array}$ & & Accepted \\
\hline $\begin{array}{l}\text { Development of human resource as a part of ICT } \\
\text { infrastructure in the banks and its role in achieving the } \\
\text { effectiveness of e-accounting information systems }\end{array}$ & 7 & 86 & Accepted \\
\hline $\begin{array}{l}\text { Development of communications and network systems as part } \\
\text { of ICT infrastructure in the banks and their role in achieving } \\
\text { the effectiveness of e-accounting information systems }\end{array}$ & 8 & 86 & Accepted \\
\hline $\begin{array}{l}\text { Development of information security as a part of ICT } \\
\text { infrastructure in the banks and its role in achieving the } \\
\text { effectiveness of e-accounting information systems }\end{array}$ & 15 & 82 & Accepted \\
\hline
\end{tabular}

\section{Descriptive Analysis of Sample Study's Response}

Respondents' answers have been analysed by using statistical package for social science; the following statistical methods have been used:

Cronbach's Alpha Test: It tests the internal consistency and reliability of measurement tool .

Arithmetic means: they identify the rate of response of respondents according to study variables .

Standard deviations: they are used for measuring the degree of absolute dispersion that represents answers' values.

One sample T-test: It is used for testing study hypotheses .

\section{Criteria of Descriptive Analysis}

Each set of questions which reflect study hypotheses has been named a field. For the purposes of data characterization and identification of respondents' opinions on questionnaire's statements and study fields, each statement has been divided according to likert five point scale as the following : 


\begin{tabular}{|l|l|l|l|l|l|}
\hline Classification & $\begin{array}{l}\text { Extremely } \\
\text { influential }\end{array}$ & Very influential & $\begin{array}{l}\text { Somewhat } \\
\text { influential }\end{array}$ & $\begin{array}{l}\text { Slightly } \\
\text { influential }\end{array}$ & $\begin{array}{l}\text { Not at all } \\
\text { influential }\end{array}$ \\
\hline Encoding & 5 & 4 & 3 & 2 & 1 \\
\hline
\end{tabular}

According to table above, adopted arithmetic mean is 3; it is extracted from a sum of values which is divided by values' number. Adopted influence ratio is 3 divided by 5 , i.e $60 \%$. Accordingly, the values of arithmetic means, reached by the study, are processed in order to interpret the data as the following:

\begin{tabular}{|c|c|c|c|c|}
\hline 1 & 2 & 3 & 4 & 5 \\
\hline Not at all influential & Slightly influential & Somewhat influential & Very influential & Extremely influential \\
\hline $1.79-1$ & $2.59-1.80$ & $2.59-2.60$ & $4.19-3.40$ & $5-4.20$ \\
\hline $\begin{array}{l}\text { The development of } \\
\text { ICT infrastructure does } \\
\text { not influence the } \\
\text { effectiveness } \\
\text { e-accounting } \\
\text { information } \\
\text { technology at all }\end{array}$ & $\begin{array}{l}\text { The development of } \\
\text { ICT infrastructure } \\
\text { influences slightly the } \\
\text { effectiveness of } \\
\text { e-accounting } \\
\text { information } \\
\text { technology }\end{array}$ & $\begin{array}{l}\text { The development of } \\
\text { ICT infrastructure } \\
\text { influences moderately } \\
\text { the effectiveness of } \\
\text { e-accounting } \\
\text { information technology }\end{array}$ & $\begin{array}{l}\text { The development of } \\
\text { ICT infrastructure } \\
\text { influences highly } \\
\text { the effectiveness of } \\
\text { e-accounting } \\
\text { information } \\
\text { technology }\end{array}$ & $\begin{array}{l}\text { The development of } \\
\text { ICT infrastructure } \\
\text { influences extremely } \\
\text { the effectiveness of } \\
\text { e-accounting } \\
\text { information } \\
\text { technology }\end{array}$ \\
\hline
\end{tabular}

\section{Data Analysis and Study Hypotheses Testing}

This section outlines and discusses the results the field study has reached in the light of study goals, questions and hypotheses .

\section{First Hypothesis Testing}

First hypothesis states that there is no statistically significant relationship between the development of ICT infrastructure, including physical and financial resources, software, databases, communication and networks, and its security and the effectiveness of accounting information systems in Jordanian banks. The study also tests the following sub-hypotheses related to the elements of ICT infrastructure. Sub-hypotheses have been firstly tested; then first main hypothesis has been tested .

\section{First Sub-hypothesis Testing}

In order to validate this hypothesis, arithmetic means and standard deviations have been extracted; the relation between the development of physical resource as a part of ICT infrastructure and the effectiveness of the effectiveness of e-accounting information systems in Jordanian banks has been measured. Table 3 outlines arithmetic means and standard deviations.

Table 3. Arithmetic mean and standard deviation of the development of physical resource as a part of ICT infrastructure and the effectiveness of e-accounting information system

\begin{tabular}{|l|l|l|l|}
\hline Statements & Arithmetic mean & Standard Deviation & Answer Orientation \\
\hline $\begin{array}{l}\text { Following statements measure to which extent the development of physical resource as a part of ICT infrastructure in the banks } \\
\text { contributes to achieve the effectiveness of accounting information systems: }\end{array}$ & 0.49 & Very influential \\
\hline $\begin{array}{l}\text { The development of using modern and sophisticated } \\
\text { hardware and devices in banking operations } \\
\text { contributes to achieve the effectiveness of } \\
\text { e-accounting information systems }\end{array}$ & 4 & 0.49 & Very influential \\
\hline $\begin{array}{l}\text { periodical update and maintenance of hardware and } \\
\text { devices contribute to achieve the effectiveness of } \\
\text { e-accounting information systems }\end{array}$ & 4.14 & Extremely influential \\
\hline $\begin{array}{l}\text { Hardware and devices used for processing and } \\
\text { entering the data are compatible with the nature and } \\
\text { number of the users and work nature and contribute to } \\
\text { achieve the effectiveness of e-accounting information } \\
\text { systems }\end{array}$ & 4.71 & 0.49 & \\
\hline $\begin{array}{l}\text { Hardware and devices are compatible with operation } \\
\text { systems applied by the banks in the manner that } \\
\text { achieves the effectiveness of e-accounting } \\
\text { information systems }\end{array}$ & 4.71 & 0.49 & Extremely influential \\
\hline $\begin{array}{l}\text { Hardware and devices of alternative energy shall be } \\
\text { provided in order to cope with power outages or and } \\
\text { malfunction of e-system, thereby achieving the } \\
\text { effectiveness of e-accounting information system }\end{array}$ & 4.71 & 0.49 & Extremely influential \\
\hline Total & 4.39 & & \\
\hline
\end{tabular}


The responses stated above have illustrated that the development of physical resource has extremely and positively influenced. In addition, they have showed that the development of using modern and advanced hardware and devices contributes to achieve the effectiveness of e-accounting information systems in the banks; total calculated arithmetic mean has been 4.39 , which is higher than hypothetical mean which is 3 . Accordingly, responses' orientation has indicated that the development of physical resources has extremely influenced .

In addition, arithmetic mean of the statements which form first sub- hypothesis has been compared with standard mark 3- hypothesis acceptance standard- by using t-test as stated in table 4 .

Table 4. Arithmetic Means, Standard Deviations and T-test of Statements which form the First Sub-Hypothesis

\begin{tabular}{|c|c|c|c|c|c|c|}
\hline $\begin{array}{l}\text { The development of } \\
\text { physical resource as a }\end{array}$ & Number & $\begin{array}{l}\text { Arithmetic } \\
\text { Mean }\end{array}$ & $\begin{array}{l}\text { Standard } \\
\text { Deviation }\end{array}$ & T-Value & $\begin{array}{l}\text { Freedom } \\
\text { Degree }\end{array}$ & $\begin{array}{l}\text { Statistical } \\
\text { Significance }\end{array}$ \\
\hline $\begin{array}{l}\text { part of ICT in the } \\
\text { banks has influenced } \\
\text { the effectiveness of } \\
\text { accounting information } \\
\text { systems: }\end{array}$ & 50 & 4.39 & 45. & 10.967 & 21 & 000. \\
\hline
\end{tabular}

Table 4 has indicated that there are statistical differences at $(=0.05)$ between arithmetic mean and standard deviation 3; T-value has been 10.967; statistical significance has been 0.000 . Thus, the hypothesis, stating that there is no statistically significant relationship between the development of physical resource as a part of ICT infrastructure and the effectiveness of e-accounting information systems in Jordanian banks, has been rejected; alternative hypothesis, stating that there is statistically significant relationship between the development of physical resource as a part of ICT infrastructure and the effectiveness of e-accounting information systems in Jordanian banks, has been accepted .

\section{Second Sub-hypothesis Testing}

In order to validate this hypothesis, arithmetic means and standard deviations have been extracted for measuring the relation between the influence of the development of software and the effectiveness of e-accounting information systems. Table 5 outlines arithmetic means and standard deviation .

Table 5. Arithmetic Means and Standard Deviation of the Impact of Software on the Effectiveness of E-Accounting Information System

\begin{tabular}{|l|l|l|l|}
\hline Statements & Arithmetic mean & Standard Deviation & Answer Orientation \\
\hline $\begin{array}{l}\text { Following statements measure to which extent the development of software as a part of ICT infrastructure in the banks } \\
\text { contributes to achieve the effectiveness of accounting information systems: }\end{array}$ & 0.90 & Very influential \\
\hline Banking Applications ( Specialized Software ( & & Very extremely \\
\hline $\begin{array}{l}\text { Latest software used by Jordanian banks } \\
\text { contributes to achieve the effectiveness of } \\
\text { accounting information systems }\end{array}$ & 4.41 & 0.90 & Extremely influential \\
\hline $\begin{array}{l}\text { The development of programs used by } \\
\text { Jordanian banks contributes to achieve } \\
\text { the effectiveness of accounting } \\
\text { information systems }\end{array}$ & 4.41 & 0.49 & Very influential \\
\hline $\begin{array}{l}\text { Banks update the software required for } \\
\text { management requirements in order to } \\
\text { achieve the effectiveness of accounting } \\
\text { information systems }\end{array}$ & 4.71 & 0.98 & Very influential \\
\hline $\begin{array}{l}\text { Using modern and advanced software in } \\
\text { data processing contributes to achieve the } \\
\text { accuracy of accounting data }\end{array}$ & 4.43 & 0.90 & Very influential \\
\hline $\begin{array}{l}\text { Using modern and advanced software } \\
\text { contributes to achieve the speediness of } \\
\text { accounting data. }\end{array}$ & 4.41 & 0.90 & Extremely influential \\
\hline $\begin{array}{l}\text { Using modern and advanced software } \\
\text { contributes to achieve the integration of } \\
\text { accounting data. }\end{array}$ & 4.41 & & \\
\hline $\begin{array}{l}\text { Jordanian banks use software which is } \\
\text { characterized by easiness and flexibility } \\
\text { of use. }\end{array}$ & 4.71 & & \\
\hline
\end{tabular}




\begin{tabular}{|c|c|c|c|}
\hline \multicolumn{4}{|l|}{ Operation systems } \\
\hline $\begin{array}{l}\text { Modern and advanced operation systems } \\
\text { used by Jordanian banks contribute to } \\
\text { achieve the effectiveness of accounting } \\
\text { information systems }\end{array}$ & 4.71 & 0.49 & Extremely influential \\
\hline $\begin{array}{l}\text { Using modern and advanced operation } \\
\text { systems contributes to achieve the } \\
\text { integration of accounting data }\end{array}$ & 4.71 & 0.49 & Extremely influential \\
\hline $\begin{array}{l}\text { Using modern and advanced software and } \\
\text { application operation systems contributes } \\
\text { to achieve the accuracy of accounting } \\
\text { data }\end{array}$ & 4.41 & 0.90 & Very influential \\
\hline $\begin{array}{l}\text { Operation systems used by Jordanian } \\
\text { banks are characterized by easiness and } \\
\text { flexibility of performing the required } \\
\text { tasks. }\end{array}$ & 4.57 & 0.53 & Extremely influential \\
\hline \multicolumn{4}{|l|}{ E-applications via cell phones: } \\
\hline $\begin{array}{l}\text { E-applications and programs via cell } \\
\text { phones and smart devices used by } \\
\text { Jordanian banks are characterized by the } \\
\text { easiness of use }\end{array}$ & 4.71 & 0.49 & Extremely influential \\
\hline $\begin{array}{l}\text { E-applications and programs via cell } \\
\text { phones and smart devices used by } \\
\text { Jordanian banks contribute to achieve the } \\
\text { effectiveness of accounting information } \\
\text { systems }\end{array}$ & 4.71 & 0.49 & Extremely influential \\
\hline $\begin{array}{l}\text { E-applications and programs via cell } \\
\text { phones and smart devices used by } \\
\text { Jordanian banks contribute to achieve the } \\
\text { speediness of accounting information } \\
\text { systems }\end{array}$ & 5 & 0 & Extremely influential \\
\hline $\begin{array}{l}\text { E-applications and programs via cell } \\
\text { phones and smart devices used by } \\
\text { Jordanian banks contribute to achieve the } \\
\text { accuracy of accounting information } \\
\text { systems }\end{array}$ & 4.71 & 0.49 & Extremely influential \\
\hline $\begin{array}{l}\text { E-applications and programs via cell } \\
\text { phones and smart devices used by } \\
\text { Jordanian banks contribute to achieve } \\
\text { banks' competition and profitability }\end{array}$ & 5 & 0 & Extremely influential \\
\hline Total & 4.50 & 0.18 & Extremely influential \\
\hline
\end{tabular}

The responses stated above have illustrated that the development of software applications and programs has extremely influenced the effectiveness of e-accounting information systems. Arithmetic mean has been 4.50, which is higher than hypothetical mean which is 3. Accordingly, responses' orientation has indicated that the development of software has extremely influenced. In addition, they have showed that using modern and advanced software contributes to achieve the accuracy, speediness, reliability and integration of e-accounting information systems in the banks.

In addition, arithmetic mean of the statements which form second hypothesis has been compared with standard mark 3- hypothesis acceptance standard- by using t-test as stated in table 6 .

Table 6. Arithmetic Means, Standard Deviations and T-test of Statements which form Second Sub Hypothesis

\begin{tabular}{|l|l|l|l|l|l|l|}
\hline the development of & Number & $\begin{array}{l}\text { Arithmetic } \\
\text { Mean }\end{array}$ & $\begin{array}{l}\text { Standard } \\
\text { Deviation }\end{array}$ & T-Value & $\begin{array}{l}\text { Freedom } \\
\text { Degree }\end{array}$ & $\begin{array}{l}\text { Statistical } \\
\text { Significance }\end{array}$ \\
$\begin{array}{l}\text { ICT in the banks has } \\
\text { influenced the } \\
\text { effectiveness of } \\
\text { accounting } \\
\text { information systems: }\end{array}$ & 50 & 4.50 & 18. & 10.835 & 21 & 000. \\
\hline
\end{tabular}

Table 6 has indicated that there are statistical differences at $(=0.05)$ between arithmetic mean and standard deviation 3; T-value has been 10.835; statistical significance has been 0.000 . Thus, this hypothesis has been 
rejected; alternative hypothesis, stating that there is statistically significant relationship between the development of software as a part of ICT infrastructure and the effectiveness of e-accounting information systems in Jordanian banks, has been accepted .

\section{Third Sub-hypothesis Testing}

In order to validate this hypothesis, arithmetic means and standard deviations have been extracted for measuring the relation between the influence of the development of database as a part of ICT infrastructure and the effectiveness of e-accounting information systems. Table 7 outlines arithmetic means and standard deviation .

Table 7. Arithmetic Means and Standard Deviation of the Impact of database on the Effectiveness of E-Accounting Information System

\begin{tabular}{|c|c|c|c|}
\hline Statements & $\begin{array}{l}\text { Arithmetic } \\
\text { mean }\end{array}$ & $\begin{array}{l}\text { Standard } \\
\text { Deviation }\end{array}$ & Answer Orientation \\
\hline \multicolumn{4}{|c|}{$\begin{array}{l}\text { Following statements measure to which extent the development of database as a part of ICT infrastructure in the banks } \\
\text { contributes to achieve the effectiveness of accounting information systems: }\end{array}$} \\
\hline $\begin{array}{l}\text { Database characterized by the flexibility, which is in line with the } \\
\text { development of IT, contributes to achieve the accuracy of } \\
\text { accounting information }\end{array}$ & 4.34 & 1.25 & Extremely influential \\
\hline $\begin{array}{l}\text { Database characterized by the flexibility and modernization, which } \\
\text { are in line with the development of IT, contributes to achieve the } \\
\text { integration of accounting information }\end{array}$ & 4.43 & 0.49 & Extremely influential \\
\hline $\begin{array}{l}\text { Database characterized by the flexibility, which is in line with the } \\
\text { development of IT, contributes to achieve the speediness of } \\
\text { accounting information }\end{array}$ & 4.43 & 0.49 & Extremely influential \\
\hline $\begin{array}{l}\text { Database characterized by the flexibility, which is in line with the } \\
\text { development of IT, contributes to achieve the reliability of } \\
\text { accounting information }\end{array}$ & 4.43 & 0.49 & Extremely influential \\
\hline $\begin{array}{l}\text { The development of database contributes to sort and tabulate } \\
\text { accounting information properly, thereby processing and providing } \\
\text { easily the appropriate information }\end{array}$ & 4.43 & 0.82 & Extremely influential \\
\hline $\begin{array}{l}\text { The development of database contributes to achieve the speediness } \\
\text { of response and access to information at the right time }\end{array}$ & 4.43 & 0.82 & Extremely influential \\
\hline $\begin{array}{l}\text { The development of database contributes to achieve the ability of } \\
\text { database to detect errors and redundancies in accounting information }\end{array}$ & 4.34 & 1.25 & Extremely influential \\
\hline $\begin{array}{l}\text { The development of database of banking accounting systems } \\
\text { contributes to provide the most useful information for planning }\end{array}$ & 5 & 0.82 & Extremely influential \\
\hline $\begin{array}{l}\text { The development of database of banking accounting systems } \\
\text { contributes to provide the most useful information for controlling }\end{array}$ & 5 & 0.82 & Extremely influential \\
\hline $\begin{array}{l}\text { The development of database of banking accounting systems } \\
\text { contributes to provide the most useful and effective information for } \\
\text { decision-making }\end{array}$ & 4.73 & 0.82 & Extremely influential \\
\hline Total & 4.73 & 0.82 & Extremely influential \\
\hline
\end{tabular}

The responses stated above have illustrated that the development of database has extremely influenced the effectiveness of e-accounting information systems. Arithmetic mean has been 4.43, which is higher than hypothetical mean which is 3 . Accordingly, responses' orientation has indicated that the development of the database has extremely influenced the effectiveness of e-accounting information systems. In addition, they have showed that using advanced database contributes to achieve an integration, confidentiality and speediness of e-accounting information systems in the banks.

In addition, arithmetic mean of the statements which form third sub- hypothesis has been compared with standard mark 3 - hypothesis acceptance standard- by using t-test as stated in table 8 .

Table 8. Arithmetic Means, Standard Deviations and T-test of Statements which form Third Sub-Hypothesis

\begin{tabular}{|c|c|c|c|c|c|c|}
\hline $\begin{array}{l}\text { the development of } \\
\text { database as a part of ICT }\end{array}$ & Number & $\begin{array}{l}\text { Arithmetic } \\
\text { Mean }\end{array}$ & $\begin{array}{l}\text { Standard } \\
\text { Deviation }\end{array}$ & T-Value & $\begin{array}{l}\text { Freedom } \\
\text { Degree }\end{array}$ & $\begin{array}{l}\text { Statistical } \\
\text { Significance }\end{array}$ \\
\hline $\begin{array}{l}\text { in the banks has } \\
\text { influenced } \\
\text { effectiveness } \\
\text { e-accounting } \\
\text { information systems: }\end{array}$ & 50 & 4.73 & 0.82 & 9.485 & 21 & 000. \\
\hline
\end{tabular}


Table 8 has indicated that there are statistical differences at $(=0.05)$ between arithmetic mean and standard deviation 3; T-value has been 9.485 ; statistical significance has been 0.000 . Thus, this hypothesis, stating that there is no statistically significant relationship between the development of database as a part of ICT infrastructure and the effectiveness of e-accounting information systems in Jordanian banks, has been rejected; alternative hypothesis, stating that there is a statistically significant relationship between the development of databases as a part of ICT infrastructure and the effectiveness of e-accounting information systems in Jordanian banks, has been accepted .

\section{Fourth Sub-hypothesis Testing}

In order to validate this hypothesis, arithmetic means and standard deviations have been extracted for measuring the relation between the influence of the development of human resource as a part of ICT infrastructure and the effectiveness of e-accounting information systems. Table 9 outlines arithmetic means and standard deviation .

Table 9. Arithmetic Means and Standard Deviation of the Impact of the development of human resource on the Effectiveness of E-Accounting Information System

\begin{tabular}{|l|l|l|l|}
\hline Statements & $\begin{array}{l}\text { Arithmetic } \\
\text { mean }\end{array}$ & \multicolumn{1}{l|}{$\begin{array}{l}\text { Standard } \\
\text { Deviation }\end{array}$} & $\begin{array}{l}\text { Answer } \\
\text { Orientation }\end{array}$ \\
\hline $\begin{array}{l}\text { Following statements measure to which extent the development of human resource as a part of ICT infrastructure in the banks } \\
\text { contributes to achieve the effectiveness of accounting information systems: }\end{array}$ & 0.53 & $\begin{array}{l}\text { Extremely } \\
\text { influential }\end{array}$ \\
\hline $\begin{array}{l}\text { Banks' managements train the accountants and develop their skills } \\
\text { which are appropriate for the development of information } \\
\text { technology }\end{array}$ & 4.43 & 0.9 & Very influential \\
\hline $\begin{array}{l}\text { The accountants are trained in advance software applications in } \\
\text { order to achieve the effectiveness of modern accounting system and } \\
\text { provide bank's management with the appropriate information }\end{array}$ & 4.14 & 0.0 & Very influential \\
\hline $\begin{array}{l}\text { The accountants participate in the processes of developing and } \\
\text { modernizing electronic systems in order to achieve the effectiveness } \\
\text { of e-accounting systems, thereby providing managements and } \\
\text { departments with the appropriate information }\end{array}$ & 4 & 0.49 & $\begin{array}{l}\text { Extremely } \\
\text { influential }\end{array}$ \\
\hline $\begin{array}{l}\text { The banks try to engage the employees in training programs in order } \\
\text { to develop a knowledge on the risks of electronic systems which } \\
\text { spoil accounting information systems }\end{array}$ & 4.29 & 0.49 & Very influential \\
\hline $\begin{array}{l}\text { The banks try to engage the accountants in choosing the software } \\
\text { which is appropriate for accounting processing }\end{array}$ & 3.71 & 0.49 & Very influential \\
\hline $\begin{array}{l}\text { The accountants are engaged in choosing the software in order to } \\
\text { prepare the reports which are appropriate for making various } \\
\text { decisions }\end{array}$ & 4.71 & 0.49 & $\begin{array}{l}\text { Extremely } \\
\text { influential }\end{array}$ \\
\hline $\begin{array}{l}\text { The accountants are trained on all security software and programs of } \\
\text { accounting systems }\end{array}$ & 4.29 & $\begin{array}{l}\text { Extremely } \\
\text { influential }\end{array}$ \\
\hline $\begin{array}{l}\text { Total } \\
\text { The ral }\end{array}$ & 4.43 & 0.49 & \\
\hline
\end{tabular}

The responses stated above have illustrated that the development of human resources has extremely influenced the effectiveness of e-accounting information systems. Arithmetic mean has been 4.43 , which is higher than hypothetical mean which is 3 . Accordingly, responses' orientation has indicated that the development of human resources has extremely influenced the effectiveness of e-accounting information systems .

In addition, arithmetic mean of the statements which form fourth sub-hypothesis has been compared with standard mark 3- hypothesis acceptance standard- by using t-test as stated in table 10 .

Table 10. Arithmetic Means, Standard Deviations and T-test of Statements which form fourth Sub-Hypothesis

\begin{tabular}{|l|l|l|l|l|l|l|}
\hline $\begin{array}{l}\text { the development of } \\
\text { human resource as a } \\
\text { part of ICT in the banks } \\
\text { has influenced the } \\
\text { effectiveness }\end{array}$ & 50 & $\begin{array}{l}\text { Arithmetic } \\
\text { Mean }\end{array}$ & $\begin{array}{l}\text { Standard } \\
\text { Deviation }\end{array}$ & T-Value & $\begin{array}{l}\text { Freedom } \\
\text { Degree }\end{array}$ & $\begin{array}{l}\text { Statistical } \\
\text { Significance }\end{array}$ \\
$\begin{array}{l}\text { e-accounting } \\
\text { information systems: }\end{array}$ & & 4.43 & 49. & 10.835 & 21 & 000. \\
\hline
\end{tabular}

Table 10 has indicated that there are statistical differences at $(=0.05)$ between arithmetic mean and standard deviation 3; T-value has been 10.835; statistical significance has been 0.000 . Thus, this hypothesis has been 
rejected; alternative hypothesis, stating that there is a statistically significant relationship between the development of human resource as a part of ICT infrastructure and the effectiveness of e-accounting information systems in Jordanian banks, has been accepted .

\section{Fifth Sub-hypothesis Testing}

In order to validate this hypothesis, arithmetic means and standard deviations have been extracted for measuring the relation between the influence of the development of communication and network system as a part of ICT infrastructure and the effectiveness of e-accounting information systems. Table 11 outlines arithmetic means and standard deviation .

Table 11 .Arithmetic Means and Standard Deviation of the Impact of the development of communication and network system on the Effectiveness of E-Accounting Information System

\begin{tabular}{|c|c|c|c|}
\hline Statements & $\begin{array}{l}\text { Arithmetic } \\
\text { mean }\end{array}$ & $\begin{array}{l}\text { Standard } \\
\text { Deviation }\end{array}$ & $\begin{array}{l}\text { Answer } \\
\text { Orientation }\end{array}$ \\
\hline \multicolumn{4}{|c|}{$\begin{array}{l}\text { Following statements measure to which extent the development of communication and network system as a part of ICT } \\
\text { infrastructure in the banks contributes to achieve the effectiveness of accounting information systems: }\end{array}$} \\
\hline $\begin{array}{l}\text { The bank develops communication networks linking the branches } \\
\text { and management according to the recent developments, and } \\
\text { maintains them periodically }\end{array}$ & 4.43 & 0.53 & $\begin{array}{l}\text { Extremely } \\
\text { influential }\end{array}$ \\
\hline $\begin{array}{l}\text { The development of communication and network systems } \\
\text { contributes to the easiness and speediness of exchanging the } \\
\text { information between various branches and departments }\end{array}$ & 4.43 & 0.53 & $\begin{array}{l}\text { Extremely } \\
\text { influential }\end{array}$ \\
\hline $\begin{array}{l}\text { The development of communication and network systems } \\
\text { contributes to achieve the integration of e-accounting information } \\
\text { systems }\end{array}$ & 4.43 & 0.9 & $\begin{array}{l}\text { Extremely } \\
\text { influential }\end{array}$ \\
\hline $\begin{array}{l}\text { The development of communication and network systems } \\
\text { contributes to achieve the confidentiality of e-accounting } \\
\text { information systems }\end{array}$ & 4.43 & 0.53 & $\begin{array}{l}\text { Extremely } \\
\text { influential }\end{array}$ \\
\hline $\begin{array}{l}\text { The development of communication and network systems } \\
\text { contributes to achieve the accuracy of e-accounting information } \\
\text { systems }\end{array}$ & 4.43 & 0.9 & $\begin{array}{l}\text { Extremely } \\
\text { influential }\end{array}$ \\
\hline $\begin{array}{l}\text { The development of communication and network systems } \\
\text { contributes to the speediness of exchanging the information between } \\
\text { the banks, branches and the central bank, thereby making accounting } \\
\text { systems more effective }\end{array}$ & 4.43 & 0.9 & $\begin{array}{l}\text { Extremely } \\
\text { influential }\end{array}$ \\
\hline $\begin{array}{l}\text { The development of communication and network systems } \\
\text { contributes to the accuracy and speediness of exchanging the } \\
\text { information between the banks and the clients, thereby making } \\
\text { accounting systems more effective }\end{array}$ & 4.43 & 0.9 & $\begin{array}{l}\text { Extremely } \\
\text { influential }\end{array}$ \\
\hline $\begin{array}{l}\text { The development of communication and network systems } \\
\text { contributes to the easiness of data access among the users and } \\
\text { provision of the best services, thereby making accounting systems } \\
\text { more effective }\end{array}$ & 4.43 & 0.9 & $\begin{array}{l}\text { Extremely } \\
\text { influential }\end{array}$ \\
\hline Total & 4.43 & 0.96 & $\begin{array}{l}\text { Extremely } \\
\text { influential }\end{array}$ \\
\hline
\end{tabular}

The responses stated above have illustrated that the development of communication and network system has extremely influenced the effectiveness of e-accounting information systems. Arithmetic mean has been 4.43, which is higher than hypothetical mean which is 3 . It means that developing the methods of exchanging and excessing the data via wireless network contributes extremely to achieve the effectiveness of accounting information systems. Accordingly, responses' orientation has indicated that the development of communication and network systems has extremely influenced the effectiveness of e-accounting information systems .

In addition, arithmetic mean of the statements which form sub-fifth hypothesis has been compared with standard mark 3 - hypothesis acceptance standard- by using t-test as stated in table 12 . 
Table 12. Arithmetic Means, Standard Deviations and T-test of Statements which form Fifth Hypothesis

\begin{tabular}{|c|c|c|c|c|c|c|}
\hline $\begin{array}{l}\text { the development of } \\
\text { communication and }\end{array}$ & Number & $\begin{array}{l}\text { Arithmetic } \\
\text { Mean }\end{array}$ & $\begin{array}{l}\text { Standard } \\
\text { Deviation }\end{array}$ & T-Value & $\begin{array}{l}\text { Freedom } \\
\text { Degree }\end{array}$ & $\begin{array}{l}\text { Statistical } \\
\text { Significance }\end{array}$ \\
\hline $\begin{array}{l}\text { network system as a part } \\
\text { of ICT in the banks has } \\
\text { influenced the } \\
\text { effectiveness of } \\
\text { e-accounting } \\
\text { information systems: }\end{array}$ & 50 & 4.43 & 96. & 10.855 & 21 & 000. \\
\hline
\end{tabular}

Table 12 has indicated that there are statistical differences at $(=0.05)$ between arithmetic mean and standard deviation 3; T-value has been 10.855; statistical significance has been 0.000 . Thus, this hypothesis has been rejected; alternative hypothesis, stating that there is statistically significant relationship between the development of communication and network as a part of ICT infrastructure and the effectiveness of e-accounting information systems in Jordanian banks, has been accepted .

\section{First Hypothesis Testing}

It states that there is no statistically significant relationship between the development of ICT infrastructure, including physical and financial resources, software, databases, communication and networks, and its security and the effectiveness of accounting information systems in Jordanian banks .

Table 13 outlines arithmetic means, standard deviations and T-test of hypotheses which form first main hypothesis.

Table 13. Arithmetic Means, Standard Deviations and T-test of the statements which form first main hypothesis

\begin{tabular}{|l|l|l|l|l|l|l|}
\hline Field Number & $\begin{array}{l}\text { Arithmetic } \\
\text { mean }\end{array}$ & $\begin{array}{l}\text { Standard } \\
\text { Deviation }\end{array}$ & T-Value & $\begin{array}{l}\text { Freedom } \\
\text { Degree }\end{array}$ & $\begin{array}{l}\text { Statistical } \\
\text { Significance }\end{array}$ \\
\hline $\begin{array}{l}\text { The contribution of the } \\
\text { development of physical } \\
\text { resources to the effectiveness } \\
\text { of e-accounting information } \\
\text { systems }\end{array}$ & 50 & 4.39 & 45. & 10.967 & 21 & 000. \\
\hline $\begin{array}{l}\text { The contribution of the } \\
\text { development of software to } \\
\text { the effectiveness of } \\
\text { e-accounting information } \\
\text { systems }\end{array}$ & 50 & 4.50 & 18. & 10.835 & 21 & 000. \\
\hline $\begin{array}{l}\text { The contribution of the } \\
\text { development of databases to } \\
\text { the effectiveness of } \\
\text { e-accounting information } \\
\text { systems }\end{array}$ & 50 & 4.73 & 0.82 & 9.485 & 21 & 000. \\
\hline $\begin{array}{l}\text { The contribution of the } \\
\text { development of human } \\
\text { resources to the effectiveness } \\
\text { of e-accounting information } \\
\text { systems }\end{array}$ & 50 & 4.43 & 49. & 10.835 & 21 & 000. \\
\hline $\begin{array}{l}\text { The contribution of the } \\
\text { development } \\
\text { communication and network } \\
\text { systems to the effectiveness } \\
\text { of e-accounting information } \\
\text { systems }\end{array}$ & & 4.43 & 96. & 10.855 & 21 & 000. \\
\hline Total & & & & & & \\
\hline
\end{tabular}

According to statistical tests, responses' orientation has indicated that the development of ICT infrastructure which consists of five components has extremely influenced the effectiveness of e-accounting information systems. Arithmetic mean has been 4.496 , which is higher than hypothetical mean which is 3 . It means that developing the components of ICT infrastructure contributes extremely to achieve the effectiveness of 
accounting information systems. Accordingly, the contribution of the development of database has occupied the first rank, followed by software in second and communication and network systems and human resources in third.

In addition, arithmetic mean of hypothesis fields which form the hypothesis has been compared with standard mark 3 - hypothesis acceptance standard- by using t-test as stated in previous table .

Table 13 has indicated that there are statistical differences at $(=0.05)$ between arithmetic mean and standard deviation 3; T-value has been 10.655; statistical significance has been 0.000 . Thus, this hypothesis has been rejected; alternative hypothesis, stating that there is statistically significant relationship between the development of ICT infrastructure, including physical and financial resources, software, databases, communication and networks, and its security and the effectiveness of accounting information systems in Jordanian banks, has been accepted .

\section{Second Hypothesis Testing}

In order to validate this hypothesis, arithmetic means and standard deviations have been extracted for measuring the relation between the influence of information security as a part of ICT infrastructure and the effectiveness of e-accounting information systems. Table 14 outlines arithmetic means and standard deviation .

Table 14. Arithmetic Mean and Standard Deviation of the Impact of the development of Information Security System on the Effectiveness of E-Accounting Information System

\begin{tabular}{|c|c|c|c|}
\hline Statements & $\begin{array}{l}\text { Arithmetic } \\
\text { mean }\end{array}$ & $\begin{array}{l}\text { Standard } \\
\text { Deviation }\end{array}$ & $\begin{array}{l}\text { Answer } \\
\text { Orientation }\end{array}$ \\
\hline \multicolumn{4}{|c|}{$\begin{array}{l}\text { Following statements measure to which extent the development of information security as a part of ICT infrastructure in the } \\
\text { banks contributes to achieve the effectiveness of e-accounting information systems in the banks }\end{array}$} \\
\hline \multicolumn{4}{|c|}{ The role of developing information security in achieving information confidentiality } \\
\hline $\begin{array}{l}\text { Developing information security and protection programs } \\
\text { contributes to maintain accounting information confidentiality }\end{array}$ & 3.71 & 49 & Very influential \\
\hline $\begin{array}{l}\text { Developing physical means of information protection contributes to } \\
\text { maintain accounting information confidentiality }\end{array}$ & 4.41 & 0.90 & Very influential \\
\hline $\begin{array}{l}\text { The banks develop policies and procedures of information } \\
\text { protection and security, thereby maintaining information } \\
\text { confidentiality }\end{array}$ & 4.71 & 0.49 & $\begin{array}{l}\text { Extremely } \\
\text { influential }\end{array}$ \\
\hline \multicolumn{4}{|c|}{$\begin{array}{l}\text { Developing information protection systems contributes to the classification of accounting information, confidentiality, thereby } \\
\text { tightening control procedures according to the degree of information confidentiality }\end{array}$} \\
\hline $\begin{array}{l}\text { Developing information security and protection such as anti-virus } \\
\text { and firewalls contributes to achieve the integrity of accounting } \\
\text { information }\end{array}$ & 4.71 & 0.49 & $\begin{array}{l}\text { Extremely } \\
\text { influential }\end{array}$ \\
\hline $\begin{array}{l}\text { Developing information security and protection programs and } \\
\text { amending and deletion processes performed by the employees, } \\
\text { clients and users contributes to achieve the integrity of accounting } \\
\text { information }\end{array}$ & 4.71 & 0.49 & $\begin{array}{l}\text { Extremely } \\
\text { influential }\end{array}$ \\
\hline $\begin{array}{l}\text { The banks develop the policies and procedures of information } \\
\text { protection and security in accordance with technical advance, } \\
\text { thereby maintaining the integrity of accounting information }\end{array}$ & 4.14 & 0.9 & Very influential \\
\hline $\begin{array}{l}\text { The development of copying systems of accounting systems and } \\
\text { shifting from traditional electronic copying processes to modern } \\
\text { systems of e-clouds contributes to achieve the integrity of } \\
\text { accounting information }\end{array}$ & 3.71 & 0.49 & Very influential \\
\hline \multicolumn{4}{|c|}{ The role of developing information security programs in ensuring information access (readiness( } \\
\hline $\begin{array}{l}\text { Developing information security and protection such as anti-virus } \\
\text { and firewalls contributes to the easiness of accessing the information }\end{array}$ & 4.71 & 0.49 & $\begin{array}{l}\text { Extremely } \\
\text { influential }\end{array}$ \\
\hline
\end{tabular}




\begin{tabular}{|l|l|l|l|}
\hline at any time & & 0.49 & $\begin{array}{l}\text { Extremely } \\
\text { influential }\end{array}$ \\
\hline $\begin{array}{l}\text { Developing information security and protection such as anti-virus } \\
\text { and firewalls contributes to the possibility of information access } \\
\text { without problems or errors }\end{array}$ & 4.71 & 0 & $\begin{array}{l}\text { Extremely } \\
\text { influential }\end{array}$ \\
\hline $\begin{array}{l}\text { The banks develop the policies and procedures of information } \\
\text { protection and security for ensuring information readiness and } \\
\text { security }\end{array}$ & 5 & 0 & $\begin{array}{l}\text { Extremely } \\
\text { influential }\end{array}$ \\
\hline $\begin{array}{l}\text { The bank has security department which control and develop all } \\
\text { activities of information security in order to ensure the continuity of } \\
\text { systems and processes }\end{array}$ & 5 & 0 & $\begin{array}{l}\text { Extremely } \\
\text { influential }\end{array}$ \\
\hline $\begin{array}{l}\text { The role of the development of information security in achieving user satisfaction } \\
\text { The development of information security contributes to increase the } \\
\text { trust of e-banking data and transactions }\end{array}$ & 5 & 0 & $\begin{array}{l}\text { Extremely } \\
\text { influential }\end{array}$ \\
\hline $\begin{array}{l}\text { the users find the systems easy to use and understandable due to the } \\
\text { development they have witnessed }\end{array}$ & 5 & 4.43 & 0.18 \\
\hline \begin{tabular}{l} 
Total \\
\hline
\end{tabular}
\end{tabular}

The results of statistical analysis have indicated that the arithmetic mean of study statements has been 4.43 which is higher than hypothetical mean. Thus, it has illustrated that the development of information security system as a part of ICT infrastructure influences the effectiveness of e-accounting information systems .

In addition, arithmetic mean of the statements which form second hypothesis has been compared with standard mark 3- hypothesis acceptance standard- by using t-test as stated in table 15 .

Table 15. Arithmetic Means, Standard Deviations and T-test of Statements which form second Hypothesis

\begin{tabular}{|l|l|l|l|l|l|l|}
\hline $\begin{array}{l}\text { The development of } \\
\text { information security } \\
\text { system as a part of ICT }\end{array}$ & Number & $\begin{array}{l}\text { Arithmetic } \\
\text { Mean }\end{array}$ & $\begin{array}{l}\text { Standard } \\
\text { Deviation }\end{array}$ & T-Value & $\begin{array}{l}\text { Freedom } \\
\text { Degree }\end{array}$ & $\begin{array}{l}\text { Statistical } \\
\text { Significance }\end{array}$ \\
\cline { 2 - 7 } $\begin{array}{l}\text { influences the } \\
\text { effectiveness of } \\
\text { e-accounting } \\
\text { information systems . }\end{array}$ & & 3.37 & 18. & 35.686 & 21 & 000. \\
\hline
\end{tabular}

Table 15 has indicated that there are statistical differences at $(=0.05)$ between arithmetic mean and standard deviation 3; T-value has been 35.686; statistical significance has been 0.000 . Thus, this hypothesis, stating that there is no statistically significant relationship between the development of information security system as a part of ICT infrastructure and the effectiveness of e-accounting information systems in Jordanian banks, has been rejected; alternative hypothesis, stating that there is statistically significant relationship between the development of information security system as a part of ICT infrastructure and the effectiveness of e-accounting information systems in Jordanian banks, has been accepted .

\section{Results and Recommendations}

\section{Results}

Based on statistical analysis, the study found the following results

There is statistically significant relationship between the development of ICT infrastructure, including physical and financial resources, software, databases, communication and networks, and its security and the effectiveness of accounting information systems in Jordanian banks .

There is statistically significant relationship between the development of physical resource as a part of ICT infrastructure and the effectiveness of e-accounting information systems in Jordanian banks . 
There is statistically significant relationship between the development of software as a part of ICT infrastructure and the effectiveness of e-accounting information systems in Jordanian banks.

There is statistically significant relationship between the development of databases as a part of ICT infrastructure and the effectiveness of e-accounting information systems in Jordanian banks.

There is statistically significant relationship between the development of human resources as a part of ICT infrastructure and the effectiveness of e-accounting information systems in Jordanian banks.

There is statistically significant relationship between the development of communication and networks as a part of ICT infrastructure and the effectiveness of e-accounting information systems in Jordanian banks.

There is no statistically significant relationship between the development of information security system as a part of ICT infrastructure and the effectiveness of e-accounting information systems in Jordanian banks.

\section{Recommendations}

The following recommendations for research have been based on the study findings :

Jordanian banks shall continually pay a special attention to all developments of information technology field and its impact on accounting information systems .

Security controls of accounting information systems shall be paid a special attention in order to ensure the confidentiality, reliability and integration of accounting information.

Training programs, workshops of information technology and accounting information systems shall be held for the employees, in particularly the accountants, in order to provide a specialized knowledge on e- systems.

The accountants shall be engaged in the stages of purchasing electronic and controlling accounting systems; their opinions shall be taken in order to provide the appropriate information and internal controls .

Implementation process of the policies and procedures of information systems and security shall be followed up and objectively evaluated .

All policies and procedures shall be amended in order to keep up with the developments of information technology systems and security and achieve the properties of accounting information .

\section{References}

Abdullah, K. A., \& Qarani, K. (2007). Banking Environment and Its Impact on Efficiency and Effectiveness of accounting Information Systems: Analytical Study on Commercial Banks in Jordan. Jordanian Journal of Humanities and Social Sciences, 10, 1-19.

Al-Ammari, A. (2004). Accounting Information System and Administrative Making-Decision in Commercial Banks. Journal of Humanities, Algeria.

Al-Dahrawy, K. A., \& Mohammad, S. K. (2002). Accounting Information Systems. New University House, Cairo, Egypt.

Al-Matarneh, G. F., \& Al-Shrairi, J. A. (2010). Impact of Information technology on Effectiveness of Accounting Information Systems in Jordanian Pharmaceutical Companies. Al-Manara Magazine, 16(1), 97-120.

Al-Qatawneh, A. (2005). Impact of Using Information Technology On Effectiveness of Accounting Information System: A Study on Bank and Insurance Facilities Listed in Amman Stock Market In the First Market (Unpublished PhD Thesis). Arab Academy of financial and banking Sciences, Amman, Jordan.

Al-Shami, A. Y. (2009). Impact of Qualitative Properties of Accounting Information On Quality of Financial Reports of Commercial Banks working in Republic of Yemen (Unpublished Master Thesis). Middle East University For Graduate Studies, Jordan .

Fadel, A. (2007). Extent of Impact of Environmental, Regulatory, Behavioural, Technological Factors On Effectiveness of Accounting Information Systems In Commercial Banks In The Republic of Yemen (Unpublished Master Thesis). Al- Al-Bayt University, Jordan.

Karfou, A. T., \& Muhsen, L. (2016). Impact of Using Automated Accounting Information Systems On The Effectiveness of Information. Diyala University. Journal of Management and Economics, Al-Mustansiriya University, Iraq.

Moskov, S. (2002). Accounting Information Systems For Making- Decisions: Concepts and Applications (Kamal Al-Din Saeed and Ahmad Hajjaj, Trans.). Mars Publishing House, Al-Riyadh: Saudi Arabia.

Qassem, A. M. (2004). Analysis and Design of Accounting Information Systems (1st ed.). Dar Al-Thaqafa For 
Printing, Publishing and Distribution.

Shubair, A. A. (2006). Role Of Accounting Information In Administrative Decision-Making: Applied Study on Joint-Stock Companies in Palestine (Unpublished Master Thesis). Gaza University, Palestine .

Syiam, W. Z. (2004). Evaluation of Computerized Accounting Information Systems In Jordanian Commercial Banks In the Light of Technological Development. Research presented to 6th Professional Scientific Occupational Conference of the Association of Certified Public Accountants, Amman, Jordan.

\section{Copyrights}

Copyright for this article is retained by the author(s), with first publication rights granted to the journal.

This is an open-access article distributed under the terms and conditions of the Creative Commons Attribution license (http://creativecommons.org/licenses/by/4.0/). 